\title{
TIME COURSE OF SALINITY ADAPTATION IN A STRONGLY EURYHALINE ESTUARINE TELEOST, FUNDULUS HETEROCLITUS: A MULTIVARIABLE APPROACH
}

\author{
W. S. MARSHALL ${ }^{1}$,*, T. R. EMBERLEY ${ }^{1}$, T. D. SINGER ${ }^{2}$, S. E. BRYSON ${ }^{1}$ AND S. D. MCCORMICK ${ }^{3}$ \\ ${ }^{1}$ Department of Biology, St Francis Xavier University, Antigonish, Nova Scotia, Canada B2G 2W5, \\ ${ }^{2}$ Vanderbilt University, Department of Anaesthesiology, Laboratory of Cellular and Molecular Physiology, \\ 504 Oxford House, 131321 st Avenue South, Nashville, TN 37232-2125, USA and ${ }^{3}$ Conte Anadromous Fish Research \\ Laboratory, Biological Resources Division, USGS, Turner's Falls, MA 01376, USA \\ *e-mail: bmarshal@stfx.ca \\ Accepted 9 March; published on WWW 6 May 1999
}

\begin{abstract}
Summary
Freshwater-adapted killifish (Fundulus heteroclitus) were transferred directly from soft fresh water to fullstrength sea water for periods of $1 \mathrm{~h}, 3 \mathrm{~h}, 8 \mathrm{~h}$ and $1,2,7,14$ and 30 days. Controls were transferred to fresh water for $24 \mathrm{~h}$. Measured variables included: blood $\left[\mathrm{Na}^{+}\right]$, osmolality, glucose and cortisol levels, basal and stimulated rates of ion transport and permeability of in vitro opercular epithelium, gill $\mathrm{Na}^{+} / \mathrm{K}^{+}$-ATPase and citrate synthase activity and chloride cell ultrastructure. These data were compared with previously published killifish cystic fibrosis transmembrane conductance regulator (kfCFTR) expression in the gills measured over a similar time course.

$24 \mathrm{~h}$ group, which showed the highest level of kfCFTR expression, had the highest plasma $\left[\mathrm{Na}^{+}\right]$and osmolality, elevated plasma cortisol levels, significantly lower opercular membrane resistance, an increased opercular membrane ion secretion rate and collapsed tubule inclusions in mitochondria-rich cells, but no change in gill $\mathrm{Na}^{+} / \mathrm{K}^{+}$-ATPase and citrate synthase activity or plasma glucose levels. Apparently, killifish have a rapid $(<1 \mathrm{~h})$ cortisol response to salinity coupled to subsequent $(8-48 h)$ expression of kfCFTR anion channel proteins in existing mitochondria-rich cells that convert transport from ion uptake to ion secretion.
\end{abstract} Plasma cortisol levels peaked at $1 \mathrm{~h}$, coincident with a rise in plasma $\left[\mathrm{Na}^{+}\right]$. At $8 \mathrm{~h}$ after transfer to sea water, a time at which previous work has shown kfCFTR expression to be elevated, blood osmolality and $\left[\mathrm{Na}^{+}\right]$were high, and cortisol levels and opercular membrane short-circuit current $\left(I_{s c} ;\right.$ a measure of $\mathrm{Cl}^{-}$secretion rate) were low. The
Key words: chloride cell, killifish, Fundulus heteroclitus, cortisol, immunoassay, salinity adaptation, Ussing chamber, citrate synthase, $\mathrm{Na}^{+} / \mathrm{K}^{+}$-ATPase, cystic fibrosis transmembrane conductance regulator (CFTR).

\section{Introduction}

Estuarine euryhaline teleosts, such as the killifish Fundulus heteroclitus, normally experience rapid salinity changes and are therefore good models for investigations of the regulation of salt transport in teleosts (Wood and Marshall, 1994; Marshall and Bryson, 1998). Adaptation to sea water in euryhaline teleosts is thought to involve the development of ion secretion pathways in the mitochondria-rich cells of the gill epithelium under the influence of cortisol, growth hormone and insulin-like growth factors (for reviews, see Bern and Madsen, 1992; Jacob and Taylor, 1983; Mancera and McCormick, 1998). In a euryhaline freshwater teleost, the Mozambique tilapia Oreochromis mossambicus, cortisol and growth hormone levels are elevated 1 and 4 days after transfer to sea water but not when these animals are transferred to brackish water or fresh water (Morgan et al., 1997). Nakano et al. (1998) similarly observed an increase in growth hormone levels after transfer of tilapia to $70 \%$ sea water, but at $12 \mathrm{~h}$ only. Transfer of tilapia through brackish water to full-strength sea water increases the size and number of mitochondria-rich cells in the opercular epithelium with a concomitant increase in $\mathrm{Cl}^{-}$ secretion rate (Foskett et al., 1981, 1983). Hence, freshwaterresident teleosts with euryhaline capability, such as the tilapia, readily adapt to salinity change over days if intermediate salinities are provided (Foskett et al., 1983; Nakano et al., 1998). Anadromous salmonid teleosts enter sea water once or twice in their life cycles, first as smolts and, in some species, as post-spawn kelts. Brook trout (Salvelinus fontinalis) show increases in plasma cortisol levels and accelerated cortisol secretion during adaptation to sea water (Nichols et al., 1985). Atlantic salmon (Salmo salar) kelts show acceleration of cortisol metabolism and utilization, but only subtle changes in plasma cortisol levels (Nichols and Weisbart, 1985). Cortisol, 
in turn, is responsible for augmentation of $\mathrm{Na}^{+} / \mathrm{K}^{+}$-ATPase activity in salmon gills in vivo (McCormick, 1996) and in organ-cultured tilapia opercular epithelium (McCormick and Bern, 1989). The typical blood ion response among anadromous teleosts transferred from fresh water through brackish water to full-strength sea water is a large increase in the levels of plasma ions $\left(\mathrm{Na}^{+}\right.$and $\left.\mathrm{Cl}^{-}\right)$that persists for at least $48 \mathrm{~h}$ in rainbow trout Oncorhynchus mykiss (Bolton et al., 1987), for $96 \mathrm{~h}$ in rainbow trout (Seddiki et al., 1995), for more than 6 days in Atlantic salmon kelts (Nichols and Weisbart, 1985), brown trout Salmo trutta (Madsen, 1990a) and rainbow trout (Madsen, 1990b) and in some cases for longer (Madsen, 1990b). Unlike anadromous fishes that change salinities a few times during their life cycle (and generally do not survive direct transfers from fresh water to full-strength sea water), estuarine-resident teleosts such as killifish must readily adapt to high and low salinity extremes and are capable of surviving direct transfer from fresh water to full-strength sea water. Killifish transferred directly to sea water have an elevated plasma osmolality (Jacob and Taylor, 1983; Zadunaisky et al., 1995), with the peak osmolality occurring $12-48 \mathrm{~h}$ after transfer. On the basis of the effects of manipulations of bathing solution osmolality on isolated killifish opercular epithelia, Zadunaisky et al. (1995) suggested that increases in plasma osmolality may be a direct cue for mitochondria-rich cells to increase $\mathrm{Cl}^{-}$secretion rate.

Killifish adapt rapidly to salinity change, and the critical period for the adaptation is in the first day or two, yet few studies have focused on this period. Indeed, Jacob and Taylor (1983) call for a 'comprehensive study of the first $24 \mathrm{~h}$ ' to reconcile the relationship between cortisol levels and $\mathrm{Na}^{+} / \mathrm{K}^{+}$ATPase activity. The present study uses a comprehensive approach, including analysis of $\mathrm{Cl}^{-}$secretion capacity by the opercular epithelium as well as enzyme and hormone assays. By doing this at a large number of time points, we can compare rates of change and the order of events to elucidate the mechanisms more clearly. Of particular interest are the events in the first $24 \mathrm{~h}$, during which changes in blood osmolality, hormonal responses and ion transport are initiated in rapidly adapting animals. Major questions include whether new chloride cells are required or whether adaptation can occur rapidly in existing cells, what the internal cues for changes in ion transport rates are, and how these changes are produced.

\section{Materials and methods}

Animals

Adult killifish (mummichog, Fundulus heteroclitus L.) of both sexes were captured in Antigonish estuary in May 1997, transferred to indoor holding facilities and adapted to brackish water (salinity $3 \mathrm{~g} \mathrm{l}^{-1}$ ) for at least 10 days at $20-25^{\circ} \mathrm{C}$ and ambient photoperiod under artificial light. Fish were fed marine fish food blend (Tetramarine, Tetra Werke, Germany) at a rate of $1.0{\mathrm{~g} 100 \mathrm{~g}^{-1} \text { body mass day }}^{-1}$, supplemented twice weekly with frozen brine shrimp. Experiments were carried out between June and August.

\section{Salinity adaptation}

Freshwater adaptation involved transfer of killifish from brackish water (salinity $3.0 \mathrm{~g} \mathrm{l}^{-1}$ ) holding facilities to dechlorinated, ultraviolet-sterilized Antigonish tap water (composition: $\quad[\mathrm{NaCl}], \quad 0.15-0.30 \mathrm{mmoll}^{-1} ; \quad\left[\mathrm{Ca}^{2+}\right]$, $0.04-0.08 \mathrm{mmol} \mathrm{l}^{-1}$, pH 5.5-6.5) in glass aquaria. The acclimation period was at least 2 weeks. The transfer of freshwater-adapted animals back to sea water was accomplished by placing pairs of animals in 101 divided aquaria containing fresh water at $20^{\circ} \mathrm{C}$ for 7 days (to acclimate to the new surroundings) then introducing a flow of sea water at the same temperature over a period of 10-12 min to complete the change to full-strength sea water. Animals were removed $1 \mathrm{~h}, 3 \mathrm{~h}$ and $8 \mathrm{~h}$, and 1, 2, 7, 14 and 30 days after transfer to sea water. A transfer control group (FWC) was treated identically to the seawater transfer animals but underwent a transfer from fresh water to fresh water; these animals were killed $24 \mathrm{~h}$ after the mock transfer. A long-term freshwater control group (LTC) was drawn from the same group of animals and treated similarly except that they were kept as a group of 10 fish and were not transferred from fresh water.

\section{Blood and tissue variables \\ Concentrations of ions, osmolality and glucose levels}

Animals were anesthetized in buffered (pH 7.1) 1:5000 MS222 in $150 \mathrm{mmoll}^{-1} \mathrm{NaCl}$, and blood was collected from the severed caudal peduncle into heparinized hematocrit tubes. Fish were killed by decapitation, and gill tissue was placed in ice-cold SEI buffer $\left(150 \mathrm{mmoll}^{-1}\right.$ sucrose, $10 \mathrm{mmoll}^{-1}$ EDTA, $50 \mathrm{mmol}^{-1}$ imidazole, $\mathrm{pH}$ 7.3) and frozen in liquid $\mathrm{N}_{2}$. Modal blood collection volume was $100 \mu$ l. Blood was centrifuged (1000 $\mathrm{g}$ for $2 \mathrm{~min}$ ), plasma was separated, and samples for the determination of cortisol levels were heatsealed in plastic ampoules. The balance of the plasma was diluted 1:10 with deionized water and stored in microcentrifuge tubes for analysis of ion levels and osmolality. Plasma $\left[\mathrm{Na}^{+}\right]\left( \pm 1 \mathrm{mmoll}^{-1}\right)$ was measured by atomic absorption spectrophotometry (Varian AA375), and plasma osmolality $( \pm 1$ mosmol kg-1) was determined on diluted plasma by freezing point depression (Osmette A, Precision Systems). Cortland's saline (full strength) with bovine serum albumin added $\left(20 \mathrm{mg} \mathrm{ml}^{-1}\right)$ was serially diluted, and it was determined that freezing point depression was a linear function of dilution down to $1: 10$, the dilution used for the plasma. In this way, the osmolality measured on dilute plasma could be extrapolated back to the osmolality of undiluted plasma, and pooling of blood samples (thus reducing sample numbers) could be avoided. Blood glucose concentration was determined spectrophotometrically on whole plasma using the glucose oxidase method (Sigma assay kit 510A).

\section{Plasma cortisol immunoassay}

Plasma cortisol levels were measured using a validated direct enzyme immunoassay as outlined by Carey and 
McCormick (1999). Sensitivity as defined by the dose-response curve was $1-400 \mathrm{ng} \mathrm{ml}^{-1}$. The lower detection limit was $0.30 \mathrm{ng} \mathrm{ml}^{-1}$. Using a pooled plasma sample, the average intra-assay variation was $5.5 \% \quad(N=10)$ and the average inter-assay variation was $8.8 \%(N=10)$.

\section{Epithelial preparation}

The opercular epithelium was removed and mounted in a modified Ussing chamber as described previously (Marshall et al., 1998b) except that the nerve supply was not dissected with the epithelium. The epithelium was supported by a nylon mesh and pinned out over the circular aperture $\left(0.125 \mathrm{~cm}^{2}\right)$ with the rim area lightly greased and bevelled to minimize edge damage. In the membrane chambers, the following epithelial electrophysiological variables were monitored: transepithelial potential $V_{\mathrm{t}}(\mathrm{mV})$, transepithelial resistance $R_{\mathrm{t}}\left(\Omega \mathrm{cm}^{2}\right)$ and short-circuit current $I_{\mathrm{sc}}\left(\mu \mathrm{A} \mathrm{cm}^{-2}\right) . I_{\mathrm{sc}}$ is expressed as positive for net gain of cations (or secretion of anions). Epithelia were clamped to $0 \mathrm{mV}$ except for short periods to allow recording of $V_{\mathrm{t}}$. A current-voltage clamp (D. Lee Co., Sunnyvale, CA, USA, or WP Instruments DVC 1000) was used to measure the epithelial variables.

\section{Bathing solutions}

A modified Cortland's saline (307 mosmol kg-1, pH 7.8) was used to bathe both membrane surfaces symmetrically; its composition was (in $\mathrm{mmol}^{-1}$ ): $\mathrm{NaCl}, 160 ; \mathrm{KCl}, 2.55 ; \mathrm{CaCl}_{2}$, 1.56; $\mathrm{MgSO}_{4}, 0.93 ; \mathrm{NaHCO}_{3}, 17.85 ; \mathrm{NaH}_{2} \mathrm{PO}_{4}, 2.97$; and glucose, 5.55. The saline had a pH of 7.8 when equilibrated with $\sim 99 \% \quad \mathrm{O}_{2} / 1 \% \mathrm{CO}_{2}$ gas mixture $\left(22^{\circ} \mathrm{C}\right)$. To mimic the high osmolality of blood plasma in animals after transfer to sea water, $\mathrm{NaCl}$ was added to the Cortland's saline to bring the osmolality to 350 mosmol kg-1 and the $\mathrm{NaCl}$ content to $186 \mathrm{mmol} \mathrm{l}^{-1}$.

\section{Radioisotopic fluxes}

Radioactive chlorine $\quad{ }^{36} \mathrm{Cl}, \quad 0.04 \mathrm{MBq} \mathrm{ml}^{-1}$ final concentration) was added to one side of the epithelium as the neutral salt, and the epithelium was left to equilibrate for $1 \mathrm{~h}$. Samples from the nonradioactive side were taken at $20 \mathrm{~min}$ intervals, mixed with a scintillation cocktail and the radioactivity counted (Packard 2000CA) to $1 \%$ error. Samples from the more radioactive side were taken initially and at the end of each hour of the experiment. Radioisotope fluxes are expressed as $\mu$ equiv $\mathrm{cm}^{-2} \mathrm{~h}^{-1}$. Fluxes were measured for two $1 \mathrm{~h}$ control periods, then dibutyryl cyclic adenosine monophosphate (db-cAMP; $0.5 \mathrm{mmoll}^{-1}$ ) and the phosphodiesterase inhibitor 3-isobutyl-1-methylxanthine (IBMX; $0.1 \mathrm{mmoll}^{-1}$ ) were added to the serosal bath. The stimulated $I_{\mathrm{sc}}$ was allowed to come to a new steady state, followed by a further $1 \mathrm{~h}$ flux measurement period.

\section{Gill enzyme assays}

$\mathrm{Na}^{+} / \mathrm{K}^{+}$-ATPase assay

$\mathrm{Na}^{+} / \mathrm{K}^{+}$-ATPase activity was determined using a kinetic microassay run in 96-well microplates at $25^{\circ} \mathrm{C}$ and read at a wavelength of $340 \mathrm{~nm}$ for $10 \mathrm{~min}$ as outlined by McCormick (1993). Gill tissue (approximately 10-15 mg, six gill filaments) was homogenized in $125 \mu \mathrm{l}$ of SEID $\left(150 \mathrm{mmoll}^{-1}\right.$ sucrose, $10 \mathrm{mmol}^{-1}$ EDTA, $50 \mathrm{mmol}^{-1}$ imidazole at $\mathrm{pH} 7.3$ with $0.1 \%$ $\mathrm{v} / \mathrm{v}$ deoxycholic acid) and centrifuged at $5000 \mathrm{~g}$ for $30 \mathrm{~s}$. Samples of the supernatant $(10 \mu \mathrm{l})$ were run in two sets of duplicates, one set containing assay mixture only and the other containing assay mixture and $0.5 \mathrm{mmoll}^{-1}$ ouabain. The resulting ouabain-sensitive ATPase activity measurement is expressed in $\mu \mathrm{mol} \mathrm{ADP} \mathrm{mg} \mathrm{m}^{-1}$ protein $^{-1}$.

\section{Citrate synthase assay}

Citrate synthase activity, an indicator of metabolic potential in mitochondria, was determined by measuring the linear rate of release of sulfhydryl-coenzyme A (CoA) with Ellman's reagents in $50 \mathrm{mmoll}^{-1}$ Tris, $0.5 \mathrm{mmoll}^{-1}$ oxaloacetate and $0.15 \mathrm{mmoll}^{-1}$ acetyl $\mathrm{CoA}(\mathrm{pH} 8.1)$ at $405 \mathrm{~nm}$ in a 96-well microplate as described by Leonard and McCormick (1998). Gill homogenates were prepared as described above for $\mathrm{Na}^{+} / \mathrm{K}^{+}$-ATPase measurement. Protein concentrations were determined using the bicinchoninic acid (BCA) protein assay (Pierce, Rockford, IL, USA). Assays were run on a THERMOmax microplate reader using SOFTmax software (Molecular Devices, Menlo Park, CA, USA).

\section{Electron microscopy}

Opercular epithelia were dissected from two animals acclimated to fresh water, from two acclimated to sea water and from two animals that had been exposed to sea water for $24 \mathrm{~h}$. Tissues were pinned out flat and fixed in $2.5 \%$ glutaraldehyde buffered with ice-cold $0.1 \mathrm{moll}^{-1}$ sodium cacodylate ( $\mathrm{pH} 7.50)$ for $1 \mathrm{~h}$ followed by an ice-cold buffer rinse for $15 \mathrm{~min}$. The tissue was cut into wedges and postfixed with $2 \%$ osmium tetroxide, $3 \%$ potassium ferricyanide $(1: 1 \mathrm{v} / \mathrm{v})$ for $1 \mathrm{~h}$ and rinsed twice in distilled water. Tissues were dehydrated through an alcohol series to $100 \%$, and infiltrated and embedded in low-viscosity Spurr's resin. One block from each animal was processed, and at least two sections from each block were examined. Sections (silver to gold) were cut using a Diatome diamond knife (Switzerland), stained with lead citrate (1 min) and uranyl acetate $(2 \mathrm{~min})$ and examined on a Philips 300 transmission electron microscope.

\section{Statistical analyses}

Values are expressed as means \pm 1 S.E.M. Time course results were analysed using single-classification analysis of variance (ANOVA) followed by a posteriori comparisons (Bonferroni's multiple-comparisons test); significant differences are indicated in the figures by non-matching letters adjacent to the means. Comparisons between two means, for example comparing the FWC control group with the test group, were performed using unpaired two-tailed $t$ tests. To compare results from unstimulated membranes with stimulated (db-cAMP/IBMX) membranes, paired $t$-tests were used. 
Fig. 1. Effects of rapid transfer from fresh water to sea water on plasma $\left[\mathrm{Na}^{+}\right]$, osmolality and hematocrit. On the time axis, -1.0 days indicates the long-term control (LTC) group, a group $(N=12)$ of freshwater-adapted fish not subjected to salinity manipulation or transfer. The points at $0 \mathrm{~h}$ are for freshwater controls (FWC), freshwater-adapted fish held as pairs in aquaria subjected to a flow through of fresh water and sampled at $24 \mathrm{~h}$. Dissimilar letters indicate a significant difference $(P<0.05$ or better) using Bonferroni's multiple-comparison test after one-way ANOVA. Values are means \pm S.E.M. ( $N=10$ for all time points).
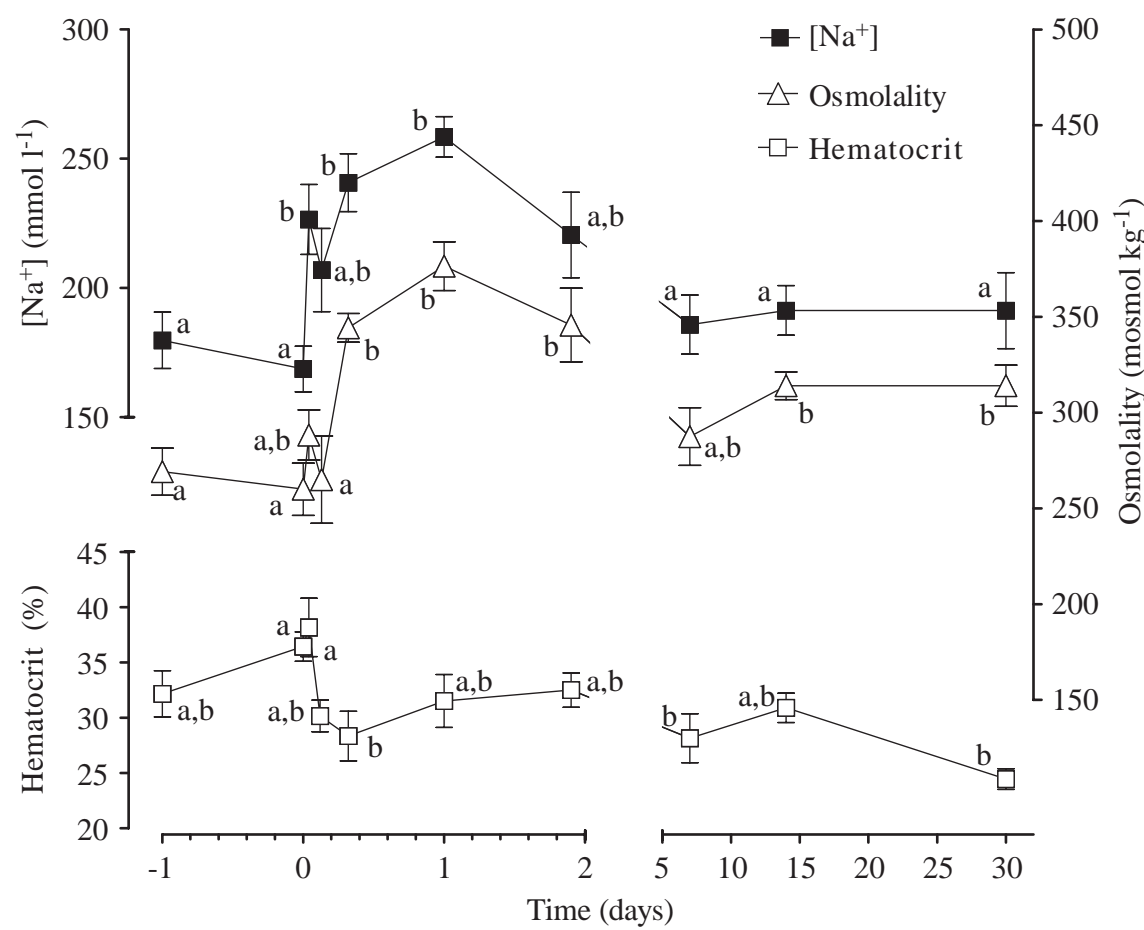

\section{Results}

Plasma $\left[\mathrm{Na}^{+}\right]$and osmolality

Direct transfer of killifish to sea water produced no mortalities, but there were clear changes in blood ion levels, osmolality and hormone levels. Plasma $\left[\mathrm{Na}^{+}\right]$was significantly elevated at $1 \mathrm{~h}, 8 \mathrm{~h}$ and $24 \mathrm{~h}$ after transfer, compared with long-term freshwater-adapted animals. Plasma $\left[\mathrm{Na}^{+}\right]$was higher than that of the freshwater transfer control (FWC) at $1 \mathrm{~h}, 8 \mathrm{~h}$ and $24 \mathrm{~h}$ (Fig. 1). The peak of $250 \mathrm{mmoll}^{-1} \mathrm{Na}^{+}$occurred $24 \mathrm{~h}$ after transfer. Plasma osmolality was elevated at $8 \mathrm{~h}, 24 \mathrm{~h}, 2$ days, 14 days and 30 days compared with FWC animals (Fig. 1). The peak osmolality, also at $24 \mathrm{~h}$, was 370 mosmol kg-1 an increase of approximately $100 \mathrm{mosmol} \mathrm{kg}^{-1}$ (or $40 \%$ ) from control levels. Whereas the pattern for plasma $\left[\mathrm{Na}^{+}\right]$suggests a return to control levels after full acclimation to sea water, plasma osmolality remained higher than that of the freshwater controls even after 30 days.

\section{Hematocrit, glucose and cortisol}

There was a transient increase in hematocrit, which was significantly elevated at $1 \mathrm{~h}$ compared with $8 \mathrm{~h}, 7$ days and 30 days (Fig. 1). Plasma cortisol level was significantly elevated at $1 \mathrm{~h}$ and $24 \mathrm{~h}$ only compared with the LTC and FWC groups (Fig. 2). Plasma cortisol levels were lowest in the FWC group at $18.8 \pm 7.5 \mathrm{ng} \mathrm{ml}^{-1}$, while the peak value occurring at $1 \mathrm{~h}$ was $164.7 \pm 19.8 \mathrm{ng} \mathrm{ml}^{-1}$. The overall pattern suggests an early $(1 \mathrm{~h})$ sharp rise in cortisol level ( $1 \mathrm{~h}$ versus $\mathrm{LTC}, \mathrm{FWC}, 14$ days and
Fig. 2. Effects of rapid transfer from fresh water to sea water on plasma cortisol levels and the rate of expression of killifish cystic fibrosis transmembrane conductance regulator ( $\mathrm{kfCFTR}$ ) relative to $\beta$-actin expression, as kfCFTR: $\beta$-actin ratio (a densitometric scan of an original Northern blot by Singer et al., 1998, with permission). Dissimilar letters indicate a significant difference $(P<0.05$ or better $)$ using Bonferroni's multiple-comparison test following one-way ANOVA. Values are means \pm S.E.M. $(N=10)$ for plasma cortisol levels. Other details are as in Fig. 1.

Killifish adaptation to sea water 1539

Fig. 3. $\mathrm{Na}^{+} / \mathrm{K}^{+}$-ATPase and citrate synthase activity in gill tissue. Values are means \pm S.E.M. $(N=10)$. ${ }^{*} P<0.05$, LTC versus FWC and $P<0.01$, LTC versus all other time periods (one-way ANOVA followed by Bonferroni's multiple-comparison test). Other details are as in Fig. 1.

30 days, $P<0.001 ; 1 \mathrm{~h}$ versus $3 \mathrm{~h}, 8 \mathrm{~h}$ and $48 \mathrm{~h}, P<0.05$ ), followed by low values at 3 and $8 \mathrm{~h}$ and a more protracted rise with a peak value at $24 \mathrm{~h}(24 \mathrm{~h}$ versus 14 days and 30 days, $P<0.01 ; 24 \mathrm{~h}$ versus $\mathrm{FWC}$ and LTC, $P<0.05$ ). The LTC and FWC groups did not differ significantly from each other $(P>0.25)$. Also shown in Fig. 2 are data taken from Singer et al. (1998): the ratio of kfCFTR expression to that of $\beta$-actin in killifish gill obtained by a densitometric scan of the results of a northern blot analysis. These ratios indicate elevated kfCFTR expression at $8 \mathrm{~h}, 24 \mathrm{~h}, 48 \mathrm{~h}, 7$ and 28 days after transfer to sea water. Peak kfCFTR expression was at $24 \mathrm{~h}$ (Fig. 2). Although these expression data come from a separate experiment, the fish were taken from the same pond (in the subsequent year), the experiments were both performed in summer, the animal care procedures were the same, and the salinity transfer and tissue collection protocols were identical. Care was taken to ensure that the two experiments were comparable.

Plasma glucose level was measured on a separate group of animals to compare $24 \mathrm{~h}$ seawater transfer animals $\left(3.63 \pm 0.35 \mathrm{mmoll}^{-1}, \quad N=6\right) \quad$ with $\quad$ FWC animals $\left(2.97 \pm 0.22 \mathrm{mmoll}^{-1}, N=6\right)$. There was no change in plasma glucose level $24 \mathrm{~h}$ after transfer to sea water compared with the mock transfer controls.
$\mathrm{Na}^{+} / \mathrm{K}^{+}$-ATPase and citrate synthase activity

There was no change in $\mathrm{Na}^{+} / \mathrm{K}^{+}$-ATPase activity at any time during the transfer to sea water. Values remained at $4 \mu \mathrm{mol} \mathrm{P}_{\mathrm{i}} \mathrm{mg}^{-1}$ protein $^{-1}$ or greater throughout the experiment (Fig. 3). Values for the LTC group were most variable, but the FWC group had a similar mean (approximately $6 \mu \mathrm{mol} \mathrm{mg} \mathrm{g}^{-1}$ protein $\mathrm{h}^{-1}$ ) with less variability. Citrate synthase activity is an indicator of metabolic potential in mitochondria and should increase if there is a net increase in the volume of mitochondria in the tissue. Citrate synthase activity followed approximately the same pattern as for $\mathrm{Na}^{+} / \mathrm{K}^{+}$-ATPase, i.e. no significant difference between FWC and seawater-acclimated animals. Interestingly, the LTC animals had a higher citrate synthase activity $\left(12.0 \pm 0.67 \mu \mathrm{mol} \mathrm{mg}^{-1}\right.$ protein $\left.^{-1}, N=10\right)$ than both the FWC group $(P<0.05)$ and the seawater transfer experimental animals $(P<0.01$, Fig. 3).

\section{Opercular epithelium electrophysiology}

$I_{\mathrm{sc}}$ for unstimulated epithelia was slightly negative in the FWC and LTC control groups and in epithelia from animals transferred to sea water for 3, 8 and $24 \mathrm{~h}$ (Fig. 4). Stimulation by db-cAMP/IBMX produced a positive current in all cases
Fig. 4. Short-circuit current $\left(I_{\mathrm{sc}}\right)$ measured in an Ussing chamber containing opercular epithelia taken from animals transferred for various times to sea water. The unstimulated $I_{\mathrm{sc}}$ for each treatment is shown (open symbols) together with the $I_{\text {sc }}$ after addition of $0.5 \mathrm{mmol}^{-1} \mathrm{db}$-cAMP plus $0.1 \mathrm{mmol}^{-1}$ IBMX to the serosal side (filled symbols) to stimulate maximal secretion rate. Dissimilar letters indicate a significant difference $(P<0.01$ or better) using Bonferroni's multiplecomparison test after one-way ANOVA. Stimulated $I_{\mathrm{sc}}$ was significantly greater than unstimulated $(P<0.05$ or better for all times except 7 days, paired $t$-test, two-tailed). Values are means \pm S.E.M. $(N=10)$. Other details are as in Fig. 1 .

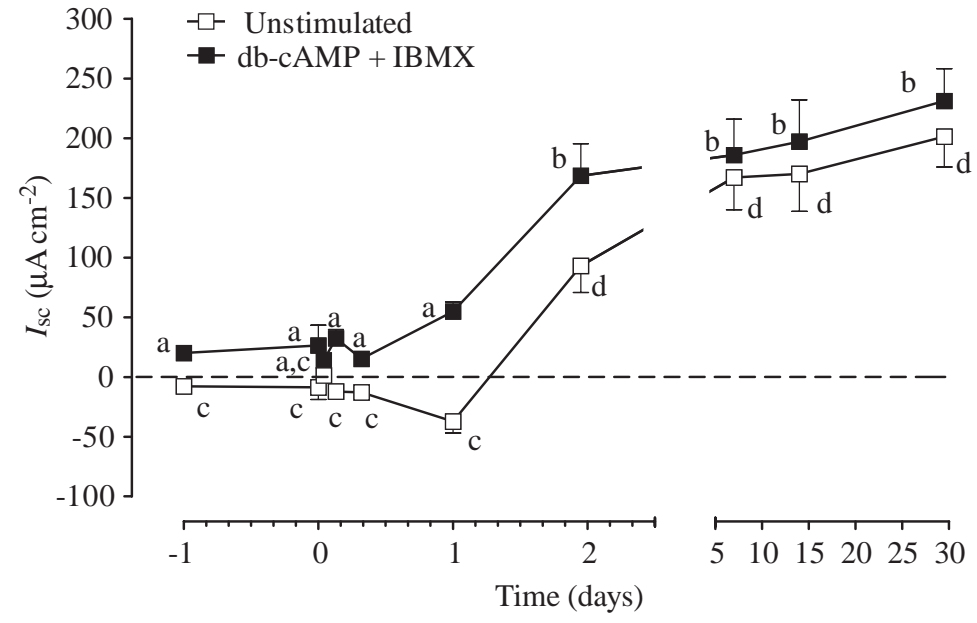


Fig. 5. Transepithelial resistance $\left(R_{\mathrm{t}}\right)$ of opercular epithelia mounted in the Ussing chamber. Values are from unstimulated epithelia (open symbols) and epithelia stimulated with $0.5 \mathrm{mmoll}^{-1} \mathrm{db}$-cAMP plus $0.1 \mathrm{mmoll}^{-1}$ IBMX (filled symbols). Dissimilar letters indicate a significant difference $(P<0.01)$ using Bonferroni's multiplecomparison test $(P<0.01$ also for 1,3 and $8 \mathrm{~h}$ compared with 1-30 day groups). Stimulated $R_{\mathrm{t}}$ was lower than unstimulated $R_{\mathrm{t}}$ at all time points except 7 days $(P<0.05$, paired $t$-test, two-tailed). Values are means \pm S.E.M. $(N=10)$. Other details are as in Fig. 1.

(corresponding to $\mathrm{Cl}^{-}$secretion). The current was significantly greater than that of both controls (FWC and LTC) by $48 \mathrm{~h}$ and remained elevated 30 days after transfer to sea water. Resting and stimulated currents were significantly different in all groups except at 7 days (paired $t$-tests), and the increase in $I_{\mathrm{sc}}$ in the stimulated group was less than $20 \%$ of the base current after 7, 14 and 30 days in sea water.

Transepithelial resistance $\left(R_{\mathrm{t}}\right)$ was initially high in the LTC and FWC groups, averaging 358 and $377 \Omega \mathrm{cm}^{2}$ (Fig. 5). Stimulation with db-cAMP/IBMX markedly reduced the $R_{\mathrm{t}}$ in LTC, FWC, $1 \mathrm{~h}, 3 \mathrm{~h}$ and $8 \mathrm{~h}$ transfer groups $(P<0.001$, paired $t$-tests), whereas stimulated $R_{\mathrm{t}}$ was only marginally lower than basal $R_{\mathrm{t}}$ in the membranes from 1,2,14 and 30 day transfers $(P<0.05$, paired $t$-tests $)$. Transfer to sea water produced a significant decrease in epithelial $R_{\mathrm{t}}$ (resting and stimulated) at $24 \mathrm{~h}$ to approximately $100 \Omega \mathrm{cm}^{2}$. For instance, the value for the FWC group was $377.2 \pm 76.4 \Omega \mathrm{cm}^{2}(N=10)$, while that for the $24 \mathrm{~h}$ group was $103.2 \pm 13.3 \Omega \mathrm{cm}^{2}(N=10)(P<0.001) . R_{\mathrm{t}} \mathrm{did}$ not change further during longer acclimation times in sea water.

The negative resting currents recorded $1-24 \mathrm{~h}$ after transfer to sea water (Fig. 4) were not expected, so we investigated

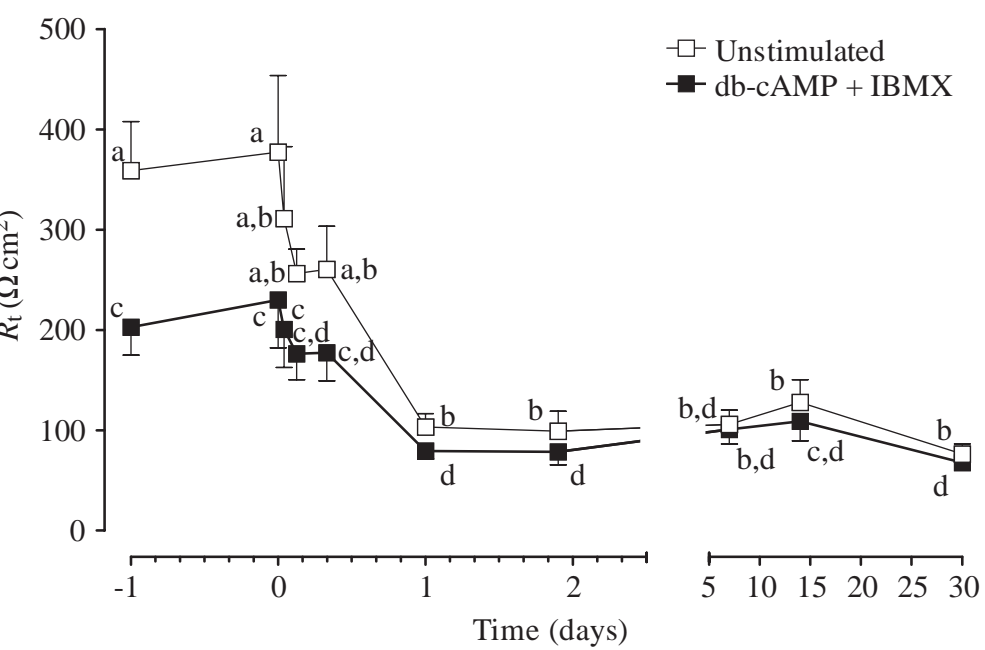

whether these were secondary effects of the osmolality of the in vitro bathing solutions being lower than that of the plasma in vivo, because large increases in plasma osmolality occurred during acclimation (see Fig. 1). Unidirectional and net $\mathrm{Cl}^{-}$ fluxes revealed that the observed negative current could be in part the result of $\mathrm{Cl}^{-}$uptake (Fig. 6) and that stimulation by IBMX and db-cAMP reversed this trend and produced a shift to a positive current and net $\mathrm{Cl}^{-}$secretion. The data presented in Fig. 4 were collected from tissues bathed in Cortland's saline of osmolality $307 \mathrm{mosmol} \mathrm{kg}-1$, while the plasma osmolality of the animals $24 \mathrm{~h}$ after transfer to sea water was higher (Fig. 1) at approximately $350 \mathrm{mosmol} \mathrm{kg}-1$. To test whether blood osmolality was a major factor in the polarity and level of current after transfer, another group of animals was transferred to sea water for $24 \mathrm{~h}$ (the period corresponding to maximal plasma osmolality; Fig. 1). The opercular epithelia from this group were mounted in the Ussing chambers and bathed initially in 307 mosmol kg-1 Cortland's saline for $1 \mathrm{~h}$, after which the osmolality was increased to 350 mosmol kg-1 by the addition of $\mathrm{NaCl}$. The $I_{\mathrm{sc}}$ was initially negative $\left(-7.0 \pm 2.2 \mu \mathrm{Acm}^{-2}, N=6\right)$ in agreement with Fig. 1 , but increasing the serosal osmolality produced a large positive $I_{\mathrm{sc}}$
Fig. 6. Unidirectional efflux $\left(J_{\mathrm{sm}}\right)$, influx $\left(J_{\mathrm{ms}}\right)$ and net flux $\left(J_{\text {net }}\right)$ of ${ }^{36} \mathrm{Cl}$ and short-circuit current $\left(I_{\mathrm{sc}}\right.$, expressed in $\mu$ equiv $\mathrm{cm}^{-2} \mathrm{~h}^{-1}$ ) across opercular epithelia transferred from fresh water to sea water for $24 \mathrm{~h}$. Membranes were mounted in Ussing chambers and monitored for $2 \mathrm{~h}$ (unstimulated) and then for $1 \mathrm{~h}$ following stimulation with $0.5 \mathrm{mmoll}^{-1}$ plus $0.1 \mathrm{mmoll}^{-1}$ db-cAMP IBMX. I $I_{\mathrm{sc}}$, short-circuit current. $* P<0.05$ (paired $t$-test) compared with hour 2 ; $* * P<0.01$ (paired $t$-test) compared with hour $2 ; * * * P<0.02$ (unpaired $t$-test) for $I_{\mathrm{sc}}$ compared with $J_{\text {net }}$ during hour $3 . \ddagger P<0.0001$ (paired $t$-test) for $I_{\mathrm{sc}}$ hour 3 compared with hour 2 . Values are means \pm S.E.M. $(N=9)$.

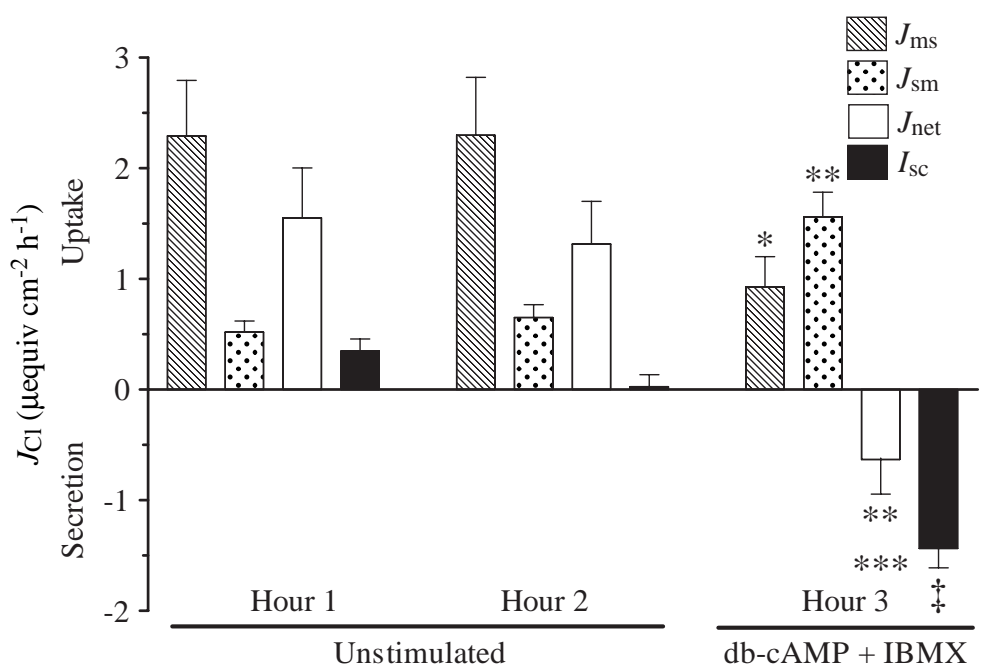


of $107 \pm 19 \mu \mathrm{A} \mathrm{cm}^{-2}(P<0.05$, paired $t$-test, $N=6)$ which was not further altered by addition of db-cAMP/IBMX $\left(90 \pm 12 \mu \mathrm{A} \mathrm{cm}^{-2}, N=6\right)$.

The discrepancy between net $\mathrm{Cl}^{-}$flux $\left(J_{\text {net }}\right)$ and $I_{\mathrm{sc}}$ in the first $2 \mathrm{~h}\left(P<0.01\right.$, unpaired $t$-tests, Fig. 6) suggests that $\mathrm{Cl}^{-}$ uptake occurs via an electrically neutral pathway. The persistent discrepancy between $I_{\mathrm{sc}}$ and $J_{\text {net }}$ after stimulation with db-cAMP and IBMX suggests that the uptake pathway is still operational under these conditions, as is also indicated by the substantial mucosal-to-serosal unidirectional flux $\left(J_{\mathrm{ms}}\right)$ (Fig. 6).

\section{Ultrastructural changes}

Samples were taken from long-term freshwater-adapted animals, those exposed to sea water for $24 \mathrm{~h}$ and long-term seawater-acclimated animals. There were numerous mitochondria-rich cells in all opercular membranes regardless of acclimation salinity, but one difference was apparent among the groups. The tubular system that is clearly present in fully acclimated animals (sea water and fresh water) (Fig. 7A,C) was noticeably reduced in the cells from the $24 \mathrm{~h}$ transfer group (Fig. 7B). This seemed to be true for the all mitochondria-rich cells regardless of their electron density (Fig. 7B).

\section{Discussion}

Killifish held in fresh water for periods greater than 30 days retain large numbers of mitochondria-rich cells in the gills (Hossler et al., 1985; Karnaky, 1991) and opercular epithelia (Wood and Marshall, 1994; Marshall et al., 1997). This situation is clearly different from the euryhaline tilapia Oreochromis mossambicus, in which the gills and opercular epithelia have few, small mitochondria-rich cells (Foskett et al., 1981; McCormick et al., 1992) and levels of $\mathrm{Na}^{+} / \mathrm{K}^{+}$ ATPase activity are low in the gills (Young et al., 1988; Borski et al., 1994; Morgan et al., 1997). Many other teleosts also maintain reduced numbers of gill chloride cells and $\mathrm{Na}^{+} / \mathrm{K}^{+}$ ATPase activity in fresh water compared with sea water (Foskett et al., 1983). Killifish live in estuaries and, hence, may encounter large increases in salinity at high tides as well as rapid decreases in salinity during heavy rains. These animals appear to retain a larger number of mitochondria-rich cells when in fresh water as an adaptation to their estuarine existence, but these cells cannot be stimulated immediately to secrete $\mathrm{Cl}^{-}$, at least to the levels normally seen in seawateradapted animals (Fig. 4; Wood and Marshall, 1994; Marshall et al., 1997). However, the data presented here indicate that normal $\mathrm{Cl}^{-}$secretion rates can be reached quickly, over a period of $24-48 \mathrm{~h}$. The observed time course involves hormonal and osmotic stimulation of cells, de novo expression of important transport proteins, an increased shunt permeability of transporting epithelia and correction of elevated levels of blood ions and osmolality. The present study of these non-steady-state changes reveals important functional

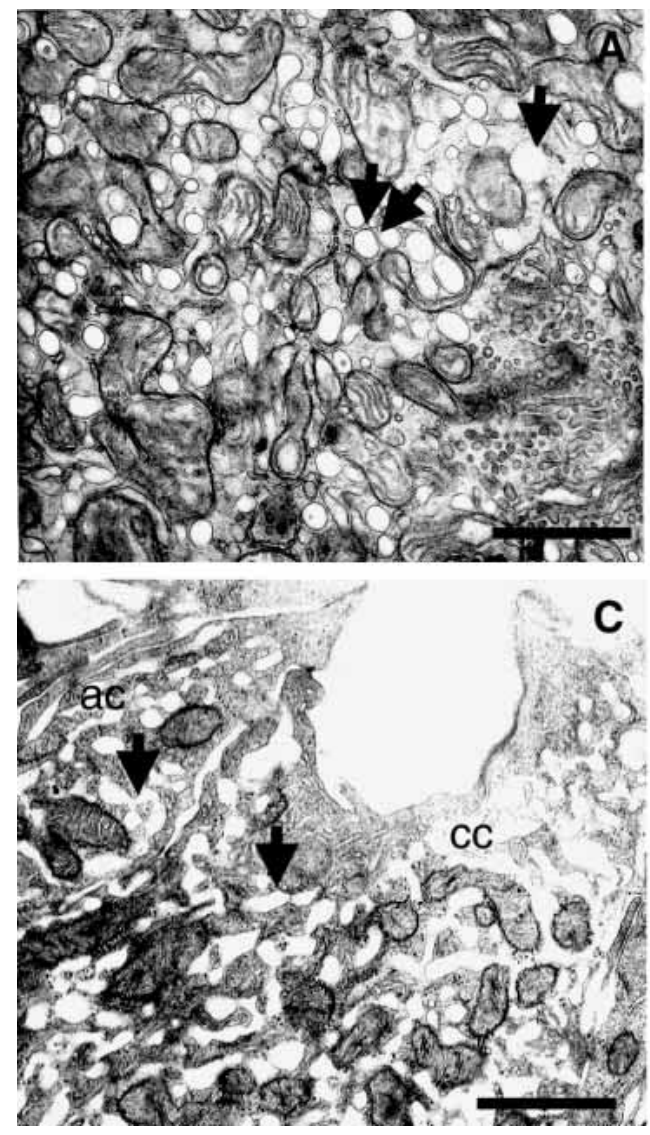

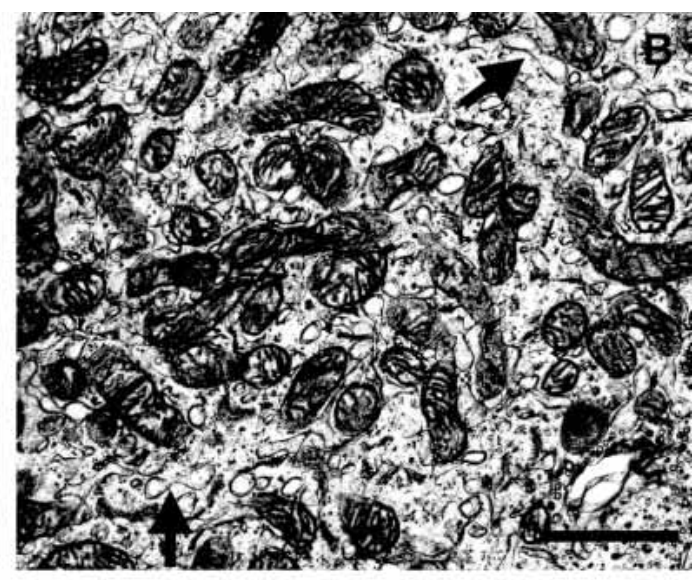

Fig. 7. Mitochondria-rich chloride cells from opercular epithelia taken from adult killifish (Fundulus heteroclitus) that were (A) freshwateracclimated, (B) transferred from fresh water to sea water for $24 \mathrm{~h}$, and (C) acclimated to sea water for more than 30 days. In sea water (C), typical chloride cells (cc) accessory cells (ac) and apical crypts were present. Note that the branched intracellular tubular system (arrows) that is clearly present in A and C is less obvious and apparently collapsed in the cells from the animals transferred to sea water for $24 \mathrm{~h}$ (arrows in B). Scale bars, $1.5 \mu \mathrm{m}$. 


\section{W. S. MARSHALL AND OTHERS}

relationships among the multiple variables measured. Whereas events that follow in time are not necessarily causally related, understanding the sequence of events at least provides excellent grounds for the formation of hypotheses and the development of a model.

Killifish show a brief increase in cortisol levels on transfer to sea water (Fig. 2) and a sustained rise in cortisol at $24 \mathrm{~h}$ that does not appear in animals transferred from fresh water to fresh water (Fig. 2). That the animals are not overtly stressed is shown by the unchanged blood glucose level (an indirect measure of stress in teleosts; Madsen, 1990a), a level that is comparable with the normal blood plasma glucose concentration of freshwater rainbow trout (3.6-4.3 $\mathrm{mmoll}^{-1}$, Madsen, 1990a; 3.8-5.2 $\mathrm{mmol}^{-1}$, McCormick et al., 1991) and killifish (3.62 $\pm 0.12 \mathrm{mmol}^{-1}$; mean \pm S.E.M., $N=5$, Mancera and McCormick, 1998). The peak in cortisol levels occurs very early in the transfer protocol, at approximately $1 \mathrm{~h}$, with cortisol returning to control levels at 3 and $8 \mathrm{~h}$ after transfer. These results confirm the pattern recorded after transfer of killifish to sea water by Jacob and Taylor (1983), where a pronounced but transient increase in cortisol concentration was seen despite the special precautions taken to eliminate handling stress during the salinity change (similar to the precautions used here). In both studies, cortisol levels returned to control levels after 4-6h. Changes in cortisol dynamics have been shown to occur in salmonids entering sea water (Nichols and Weisbart, 1985; Nichols et al., 1985) and involve a greater utilization and metabolism of steroids after transfer. An increase in cortisol utilization by the target tissues would explain the low levels of plasma cortisol observed at 3 and $8 \mathrm{~h}$ post-transfer. The second, less-dramatic peak in cortisol at $24 \mathrm{~h}$ may represent a reduction in cortisol utilization, because the target tissues have effectively switched over to the expression of seawater-adaptive proteins by this time. Of particular importance is the apical membrane anion channel $\mathrm{Cl}^{-}$secretory epithelium that has been described in killifish $\mathrm{Cl}^{-}$cells (Marshall et al., 1995) and later cloned, sequenced and identified as a homolog of cystic fibrosis transmembrane conductance regulator, kfCFTR (Singer et al., 1998). Supporting evidence for this comes from Singer et al. (1998), who found, for the same species and transfer protocol, increased kfCFTR expression (relative to $\beta$-actin expression) at $8 \mathrm{~h}$, peaking at $24 \mathrm{~h}$ and still remaining at levels higher than those in fresh water after 30 days in sea water. It is reasonable to suggest that the most dramatic rise in cortisol levels (at approximately $1 \mathrm{~h}$ ) is a major cue for the initiation of kfCFTR expression (at $8 \mathrm{~h}$ ) and that kfCFTR expression is linked to the development of the significant enhancement of $\mathrm{Cl}^{-}$secretion that occurs $24 \mathrm{~h}$ after transfer.

The relationship between changes in $\mathrm{Na}^{+} / \mathrm{K}^{+}$-ATPase activity and seawater acclimation in killifish is variable. In some cases, there is a clear increase in gill $\mathrm{Na}^{+} / \mathrm{K}^{+}$-ATPase activity following acclimation to sea water (Jacob and Taylor, 1983), but in transfers from brackish water to sea water, Mancera and McCormick (1998) found no change after $24 \mathrm{~h}$ in sea water, nor did activity alter in the present study. This lack of change may be related to the retention of large numbers of mitochondria-rich cells in freshwater-adapted animals and a concomitant high level of $\mathrm{Na}^{+} / \mathrm{K}^{+}$-ATPase activity in these fish $\left(5.5 \pm 0.1 \mu \mathrm{mol} \mathrm{P}_{\mathrm{i}} \mathrm{mg}^{-1}\right.$ protein $\mathrm{h}^{-1}$; Mancera and McCormick, 1998; 5.8 $\pm 0.4 \mu \mathrm{mol} \mathrm{P}_{\mathrm{i} \mathrm{mg}} \mathrm{m}^{-1}$ protein $^{-1}$; this study; Fig. 3) compared with other species such as tilapia in which there are few $\mathrm{Cl}^{-}$cells and $\mathrm{Na}^{+} / \mathrm{K}^{+}$-ATPase activity is low $\left(0.65 \pm 0.11 \mu \mathrm{mol} \mathrm{ADP} \mathrm{mg}{ }^{-1}\right.$ protein $\mathrm{h}^{-1}$; Morgan et al., 1997). Overall, our data support the suggestion that cortisol does not act alone to increase $\mathrm{Na}^{+} / \mathrm{K}^{+}$-ATPase activity; cortisol levels were clearly elevated, but $\mathrm{Na}^{+} / \mathrm{K}^{+}$-ATPase activity was unchanged. Growth hormone and insulin-like growth factor I (IGF-I) are possible candidates for hormones associated more directly with augmentation of $\mathrm{Na}^{+} / \mathrm{K}^{+}$-ATPase (Mancera and McCormick, 1998).

The role of plasma osmolality in the regulation of ion transport rates in killifish has been investigated by Zadunaisky et al. (1995), who found that a hyperosmotic shock caused rapid increases in $\mathrm{Cl}^{-}$secretion rate. Our data confirm this finding and extend the previous work in that opercular epithelia from animals recently transferred to sea water have mitochondria-rich cells that secrete $\mathrm{Cl}^{-}$only at the elevated plasma osmolality experienced by the animal. Reductions from the in vivo osmolality result in pronounced reductions in the rate of $\mathrm{Cl}^{-}$secretion. Therefore, killifish mitochondria-rich cells appear to respond to rapid changes in plasma osmolality by increasing $\mathrm{Cl}^{-}$secretion following cell shrinkage and decreasing secretion following cell swelling. The new higher or lower transport rate is kept constant while the cell readjusts within a few hours to the new osmolality (presumably by cell volume regulation). In preliminary work, we have shown that the reductions in $\mathrm{Cl}^{-}$secretion resulting from cell swelling are a purely osmotic (not ionic) response that is not mediated by intracellular $\mathrm{Ca}^{2+}$ or by reductions in cyclic AMP levels (Marshall et al., 1998a). It is not known how widely distributed this characteristic of autoregulation of $\mathrm{Cl}^{-}$secretion by plasma osmolality is, but potentially it may be present in many euryhaline animals.

There were no differences in gill citrate synthase activity with seawater adaptation, consistent with the relatively stable glycolytic enzyme levels measured during adaptation of tilapia to $70 \%$ sea water (Nakano et al., 1998). The curious result of a significantly higher citrate synthase activity in the long-term freshwater controls compared with the other groups requires further examination. The only difference between the longterm controls and the freshwater transfer group was that the transfer animals were kept as pairs (for 1 week prior to the mock transfer), while the long-term animals were kept as a group of 10. Because the mock transfer produced no differences in any other variable, it is possible that this change in citrate synthase activity is related to the schooling behavior of these fish.

The ultrastructural changes observed in chloride cells $24 \mathrm{~h}$ after transfer suggest that the tubular system, the main location of $\mathrm{Na}^{+} / \mathrm{K}^{+}$-ATPase in chloride cells (Hootman and Philpott, 1979; Ernst and Mills, 1980), has been altered in some way. 
The tubular system components, normally fluid-filled and approximately $1 \mu \mathrm{m}$ in width, are not as clear in the $24 \mathrm{~h}$ transfer group as in chloride cells from seawater- or freshwateracclimated fish (Fig. 7). This could be the result of turnover of the tubular system or the loss of the fluid in the system. It is difficult to explain an osmotically driven collapse of the tubules unless it is the result of a regulatory volume increase that drives ions and fluid from the tubular system into the cytoplasm and thus tends to collapse the tubules. It is reasonable to assume that the rise in plasma osmolality (during the first $24 \mathrm{~h}$ in sea water, Fig. 1) will induce osmotic shrinkage and a subsequent regulatory volume increase in the chloride cells. Alternatively, membrane trafficking processes could remove portions of the system and replace them progressively during salinity acclimation. To our knowledge, the ultrastructure of chloride cells has not been examined previously during the salinity adaptation process, but in fully acclimated animals only. The present results indicate that further examination of cell ultrastructure during the periods of greatest change could reveal functionally important information.

This study was supported by NSERC Canada grant to W.S.M. and NSERC USRA scholarships to T.R.E. Data, in part, are from the BSc Honours Research of T.R.E. Many thanks to A. L. MacDonald and J. Vandenheuvel for prizewinning animal care and M. F. O'Dea and J. B. Carey for excellent technical assistance.

\section{References}

Bern, H. A. and Madsen, S. S. (1992). A selective survey of the endocrine system of the rainbow trout (Oncorhynchus mykiss) with emphasis on the hormonal regulation of ion balance. Aquaculture 100, 237-262.

Bolton, J. P., Collie, N. L., Kawauchi, H. and Hirano, T. (1987). Osmoregulatory actions of growth hormone in rainbow trout (Salmo gairdneri). J. Endocr. 112, 63-68.

Borski, R. J., Yoshikawa, J. S. M., Madsen, S. S., Nishioka, R. S., Zabetian, C., Bern, H. A. and Grau, E. G. (1994). Effects of environmental salinity on pituitary growth hormone content and cell activity in the euryhaline tilapia, Oreochromis mossambicus. Gen. Comp. Endocr. 95, 483-494.

Carey, J. B. and McCormick, S. D. (1999). Atlantic salmon smolts are more responsive to handling and confinement stress than parr. Aquaculture 168, 237-253.

Ernst, S. A. and Mills, J. W. (1980). Autoradiographic localization of tritiated ouabain-sensitive sodium pump sites in ion transporting epithelia. J. Histochem. Cytochem. 28, 72-77.

Foskett, J. K., Bern, H. A., Machen, T. E. and Connor, M. (1983). Chloride cells and the hormonal control of teleost osmoregulation. J. Exp. Biol. 106, 255-281.

Foskett, J. K., Logsdon, C. D., Turner, T., Machen, T. and Bern, H. A. (1981). Differentiation of the chloride extrusion mechanism during seawater adaptation of a teleost fish, the cichlid Sarotherodon mossambicus. J. Exp. Biol. 93, 209-224.

Hootman, S. R. and Philpott, C. W. (1979). Ultracytochemical localization of $\mathrm{Na}^{+}, \mathrm{K}^{+}$-activated ATPase in chloride cells from the gills of a euryhaline teleost. Anat Rec. 193, 99-130.
Hossler, F. E., Musil, G., Karnaky, K. J., Jr and Epstein, F. H. (1985). Surface ultrastructure of the gill arch of the killifish, Fundulus heteroclitus, from seawater and fresh water, with special reference to the morphology of the apical crypts of chloride cells. J. Morph. 185, 377-386.

Jacob, W. F. and Taylor, M. H. (1983). The time course of seawater acclimation in Fundulus heteroclitus L. J. Exp. Zool. 228, 33-39.

Karnaky, K. J., Jr (1991). Teleost osmoregulation: Changes in the tight junction in response to the salinity of the environment. In The Tight Junction (ed. M. Cereijido), pp. 175-185. Boca Raton, FL: CRC Press.

Leonard, J. B. K. and McCormick, S. D. (1999). The effect of migration distance and timing on metabolic enzyme activity in an anadromous clupeid, the American shad (Alosa sapidissia). Fish Physiol. Biochem. 20, 163-179.

Madsen, S. S. (1990a). The role of cortisol and growth hormone in seawater adaptation and development of hypoosmoregulatory mechanisms in sea trout parr (Salmo trutta trutta). Gen Comp. Endocr. 79, 1-11.

Madsen, S. S. (1990b). Cortisol treatment improves the development of hypoosmoregulatory mechanisms in the euryhaline rainbow trout, Salmo gairdneri. Fish Physiol. Biochem. 8, 45-52.

Mancera, J. M. and McCormick, S. D. (1998). Evidence for growth hormone/insulin-like growth factor I axis regulation of seawater acclimation in the euryhaline teleost Fundulus heteroclitus. Gen. Comp. Endocr. 111, 103-112.

Marshall, W. S. and Bryson, S. E. (1998). Transport mechanisms of seawater chloride cells: An inclusive model of a multifunctional cell. Comp. Biochem. Physiol. 119A, 97-106.

Marshall, W.S., Bryson, S. E., Darling, P., Whitten, C., Patrick, M., Wilkie, M., Wood, C. M. and Buckland-Nicks, J. (1997). $\mathrm{NaCl}$ transport and ultrastructure of opercular epithelium from a freshwater-adapted euryhaline teleost, Fundulus heteroclitus. J. Exp. Zool. 277, 23-37.

Marshall, W.S., Bryson, S. E. and Luby, T. (1998a). Control of epithelial $\mathrm{Cl}^{-}$secretion by basolateral osmolality in the euryhaline teleost Fundulus heteroclitus. FASEB. J. 12, A122 (abstract).

Marshall, W. S., Bryson, S. E., Midelfart, A. and Hamilton, W. F. (1995). Low conductance anion channel activated by cAMP in teleost Cl-secreting cells. Am. J. Physiol. 268, R963-R969.

Marshall, W. S., DuQuesnay, R. M., Gillis, J. M., Bryson, S. E. and Liedtke, C. M. (1998b). Neural modulation of salt secretion in teleost opercular epithelium by $\alpha$-adrenergic receptors and inositol 1,4,5-trisphosphate. J. Exp. Biol. 201, 1959-1965.

McCormick, S. D. (1993). Methods for non-lethal gill biopsy and measurement of $\mathrm{Na}^{+}, \mathrm{K}^{+}$-ATPase activity. Can. J. Fish. Aquat. Sci. 50, 656-658.

McCormick, S. D. (1996). Effects of growth hormone and insulinlike growth factor I on salinity tolerance and gill $\mathrm{Na}^{+}, \mathrm{K}^{+}$-ATPase in Atlantic salmon (Salmo salar): Interaction with cortisol. Gen. Comp. Endocr. 101, 3-11.

McCormick, S. D. and Bern, H. A. (1989). In vitro stimulation of $\mathrm{Na}^{+}, \mathrm{K}^{+}$-ATPase activity and ouabain binding by cortisol in coho salmon gill. Am. J. Physiol. 256, R707-R715.

McCormick, S. D., Hasegawa, S. and Hirano, T. (1992). Calcium uptake in the skin of a freshwater teleost. Proc. Natl. Acad. Sci. USA 89, 3635-3638.

McCormick, S. D., Sakamoto, T., Hasegawa, S. and Hirano, T. (1991). Osmoregulatory actions of insulin-like growth factor I in rainbow trout (Oncorhynchus mykiss). J. Endocr. 130, 87-92.

Morgan, J. D., Sakamoto, T., Grau, E. G. and Iwama, G. K. 


\section{W. S. MARSHALL AND OTHERS}

(1997). Physiological and respiratory responses of the Mozambique tilapia (Oreochromis mossambicus) to salinity acclimation. Comp. Biochem. Physiol. 117A, 391-398.

Nakano, K., Tagawa, M., Takemura, A. and Hirano, T. (1998). Temporal changes in liver carbohydrate metabolism associated with seawater transfer in Oreochromis mossambicus. Comp. Biochem. Physiol. 119B, 721-728.

Nichols, D. J. and Weisbart, M. (1985). Cortisol dynamics during seawater adaptation of Atlantic salmon Salmo salar. Am. J. Physiol. 248, R651-R659.

Nichols, D. J., Weisbart, M. and Quinn, J. (1985). Cortisol kinetics and fluid distribution in brook trout (Salvelinus fontinalis). $J$. Endocr. 107, 57-69.

Seddiki, H., Maxime, V., Boeuf, G. and Peyraud, C. (1995). Effects of growth hormone on plasma ionic regulation, respiration and extracellular acid-base status in trout (Oncorhynchus mykiss) transferred to seawater. Fish Physiol. Biochem. 14, 279-288.
Singer, T. D., Tucker, S. J., Marshall, W. S. and Higgins, C. F. (1998). A divergent CFTR homologue: highly regulated salt transport in the euryhaline teleost F. heteroclitus. Am. J. Physiol. 274, C715-C723.

Wood, C. M. and Marshall, W. S. (1994). Ion balance, acid-base regulation and chloride cell function in the common killifish, Fundulus heteroclitus - A euryhaline estuarine teleost. Estuaries 17, 34-52.

Young, P. S., McCormick, S. D., Demarest, J. R., Lin, R. J., Nishioka, R. S. and Bern, H. A. (1998). Effects of salinity, hypophysectomy and prolactin on whole-animal transepithelial potential in the tilapia Oreochromis mossambicus. Gen. Comp. Endocr. 71, 389-397.

Zadunaisky, J. A., Cardona, S., Au, L., Roberts, D. M., Fisher, E., Lowenstein, B., Cragoe, E. J., Jr, and Spring, K. R. (1995). Chloride transport activation by plasma osmolarity during rapid adaptation to high salinity of Fundulus heteroclitus. J. Membr. Biol. 143, 207-217. 